\title{
KEDUDUKAN DEWAN PERWAKILAN RAKYAT DALAM PENETAPAN DAN PENGAWASAN APBN DI INDONESIA
}

\author{
Julpikar \\ Fakultas Hukum Universitas Muhammadiyah Sumatera Utara \\ E-mail: julfikarsyarno@gmail.com
}

\begin{abstract}
The one of House of Representatives' role (DPR) is overseeing. DPR is as the one of determinant of Indonesia government. DPR has crucial role and function for Indonesia citizen lives in all aspects. In constitution aspect, DPR has role to determine budget together with government. Budgeting function needs to be supervised if it's not, the Indonesia development program will not be on target. DPR should give the guidance in budgeting process, because it is related of State Budget.
\end{abstract}

Kata Kunci: Dewan Perwakilan Rakyat, Penetapan, Pengawasan, Anggaran

\section{A. Latar Belakang}

Sistem ketatanegaraan Indonesia sering berubah seiring dengan perubahan rezim yang berkuasa. Pada masa Orde Baru, fungsi dan tugas Dewan Perwakilan Rakyat (DPR) hanya sebagai "tukang stempel" atau lembaga stempel atas keinginan dan kehendak politik pemerintah atau pihak eksekutif (Marbun 1992: 1). Dengan paradigm seperti itu dipastikan bahwa DPR tidak akan pernah bekerja sesuai dengan tujuan pokok dan fungsinya.

Ketika reformasi terjadi pada pertengahan Mei 1998, yang diiringi dengan tuntutan masyarakat untuk mengembalikan fungsi anggota legislatif sesuai dengan tujuan pembentukannya, maka mulailah peran dan fungsi anggota DPR sebagaimana yang dicita-citakan. Memang tidak tertutup kemungkinan bahwa bukan hanya orang awam, tetapi juga sejumlah anggota DPR sendiri belum pernah mengkaji secara detail dan mendasar bagaimana sebenarnya posisi DPR dalam rumusan UUD 1945.

Perubahan pertama UUD 1945 telah mengubah kekuasaan membentuk undang-undang, dari yang semula dipegang oleh presiden beralih menjadi wewenang DPR. Penataan pelaksanaan fungsi legislasi DPR ini, tentunya akan 
memiliki pengaruh terhadap kualitas pembentukan undang-undang di Indonesia (Yuliandri 2011: 1). Undang-undang merupakan landasan hukum yang menjadi dasar pelaksanaan dari seluruh kebijakan yang akan dibuat oleh pemerintah (Yuliandri 2011: 1). Legal policy yang dituangkan dalam undang-undang, menjadi sebuah sarana rekayasa sosial, yang memuat kebijaksanaan yang hendak dicapai oleh pemerintah, untuk mengarahkan masyarakat menerima nilai-nilai baru.

Substansi UUD 1945 hasil amandemen yang terkait dengan "hal keuangan," menunjukkan bahwa hukum keuangan negara memiliki kaidah hukum yang tertulis. Sebenarnya kaidah hukum tertulis sangat memegang peranan penting dalam perhubungan hukum saat ini maupun ke depannya, karena dibutuhkan suatu kepastian hukum yang bersumber dari kaidah hukum tertulis, sehingga sangat diharapkan munculnya kaidah hukum tertulis dalam rumusan atau pengertian hukum keuangan negara sebagai hukum positif.

Hukum keuangan negara adalah sekumpulan kaidah hukum tertulis yang mengatur hak dan kewajiban Negara yang dapat dinilai dengan uang (Jafar 2013: 2), termasuk uang dan barang yang dikuasai oleh negara terkait dengan pelaksanaan hak dan kewajiban tersebut. Pengertian barang yang dikuasai oleh Negara dapat berupa barang bergerak maupun barang tidak bergerak, berwujud dan barang tidak berwujud (Jafar 2013: 2).

Landasan hukum keuangan negara tercantum dalam Pasal 23 UUD 1945, yang menentukan sebagai berikut:

Ayat (1): Anggaran Pendapatan dan Belanja Negara sebagai wujud dari pengelolaan keuangan negara ditetapkan setiap tahun dengan undangundang dan dilaksanakan secara terbuka dan bertanggungjawab untuk sebesar-besarnya kemakmuran rakyat.

Ayat (2): Rancangan Undang-undang Anggaran Pendapatan dan Belanja Negara diajukan oleh Presiden untuk dibahas bersama Dewan Perwakilan Rakyat dengan memperhatikan Dewan Perwakilan Daerah.

Ayat (3): Apabila Dewan Perwakilan Rakyat tidak menyetujui rancangan Anggaran Pendapatan dan Belanja Negara yang diusulkan oleh 
Presiden, Pemerintah menjalankan Anggaran Pendapatan dan Belanja Negara tahun yang lalu.

Terkait dengan keuangan negara ini, maka dalam rangka mewujudkan good governance penyelenggaraan pemerintah negara guna mendukung keinginan untuk menciptakan pemerintah yang bersih, akuntabel dan transparan dalam pengelolaan keuangan Negara, DPR memiliki fungsi-fungsi dalam hal ini diatur dalam pasal 20 A ayat (1) UUD 1945, menyatakan bahwa DPR memiliki fungsi legislasi, fungsi anggaran dan fungsi pengawasan. Sehubungan hal ini, maka DPR tentunya mempunyai fungsi dan kewenangan untuk menetapkan Anggaran Pendapatan dan Belanja Negara (APBN), sekaligus mengawasi pelaksanaannya. Hal ini tentunya menarik untuk ditelaah lebih lanjut, sehingga perlu dilakukan penelitian untuk menjawab permasalahan yang terkait dengan kedudukan DPR dalam penetapan dan pengawasan APBN.

\section{B. Metode Penelitian}

Jenis penelitian ini adalah penelitian hukum normatif, yaitu penelitian yang datanya bersumber pada data sekunder. Sifat penelitian ini adalah deskriptif, yang bertujuan untuk memberikan gambaran tentang gejala-gejala sosial yang terkait dengan masalah penetapan dan pengawasan keuangan negara. Sumber data penelitian berupa bahan hukum primer, bahan hukum sekunder dan bahan hukum tersier. Metode pengumpulan data dilakukan menggunakan teknik studi dokumen atau studi literatur, selanjutnya data yang terkumpul dianalisis dengan menggunakan metode analisis kualitatif.

\section{Hasil Penelitian dan Analisis}

\section{Fungsi DPR}

DPR selain sebagai badan legislatif juga DPR sebagai lembaga kontrol (pengawas) terhadap jalannya pemerintahan. Fungsi pengawasan oleh DPR diatur dalam Pasal 20 A ayat (1) UUD 1945, yang menentukan bahwa DPR memiliki fungsi legislasi, fungsi anggaran, dan fungsi pengawasan dan dalam penjelasan UUD 1945, mempunyai arti yang sangat penting karena DPR dapat mengusulkan 
kepada MPR untuk meminta pertanggunganjawaban dari Presiden dalam sidang istimewa apabila presiden dianggap telah melanggar ketentuan yang ada.

Menurut Ismail Suny (2004: 13) dikatakan bahwa fungsi kontrol oleh DPR (real parliamentary control) dapat dilakukan dalam 3 (tiga) bentuk, yaitu

a. Control of executive menetapkan hak-hak DPR, yaitu:

1) mengajukan pertanyaan bagi masing-masing anggota;

2) meminta keterangan (interpelasi);

3) mengadakan penyilidikan (angket);

4) mengajukan perubahan (amandemen);

5) mengajukan usul pernyataan pendapat; dan

6) mengajukan/menganjurkan seseorang, jika ditentukan oleh peraturan perundang-undangan

b. Control of expenditure, yang berdasarkan Pasal 23 ayat (1) UUD 1945 beserta penjelasan-nya mengatur hak DPR untuk bersama-sama pemerintah menetapkan APBN. Dihubungkan dengan adanya Badan Pemeriksa Keuangan yang ditugaskan memeriksa tanggung jawab tentang keuangan negara, dan hasil pemeriksaan itu harus diberitahukan kepada DPR, maka pengawasan APBN ini sebenarnya dapat dilakukan secara efektif.

c. Control of taxation, yang berdasarkan Pasal 23 A UUD 1945, maka pajak dan pungutan lain yang bersifat memaksa untuk keperluan negara diatur dengan undang-undang, dan dengan demikian segala tindakan yang menempatkan beban kepada rakyat sebagai pajak dan lain-lainnya harus ditetapkan dengan persetujuan DPR.

Fungsi DPR pada dasarnya adalah sebagai lembaga perwakilan tempat masyarakat untuk menyampaikan aspirasi dan menyuarakan kepentingannya, lewat lembaga ini akan keluar kebijakan yang menjadi dasar bagi presiden dalam menjalankan roda pemerintah. DPR-RI Indonesia dalam sistem politik dan sistem pemerintahan Negara Republik Indonesia merupakan salah satu lembaga tinggi negara dan sebagai wahana melaksanakan demokrasi Pancasila. Dalam sistem pemerintanan demokrasi, lembaga perwakilan rakyat merupakan perangkat kenegaraan yang sangat penting selain perangkat-perangkat kenegaraan yang lain, 
baik yang bersifat infrastruktur maupun supra struktur politik. Setiap pemerintahan yang menganut sistem demokrasi selalu didasari suatu ide bahwa warga negara seharusnya dilibatkan dalam setiap proses pengambilan keputusan politik.

Fungsi badan perwakilan rakyat yang mencirikan demokrasi modern ini memperkenalkan nama badan legislatif atau badan pembuat undang-undang kepadanya. Fungsi ini dapat diartikan sebagai fungsi legislasi. Melalui fungsi ini parlemen menunjukkan bahwa dirinya sebagai wakil rakyat dengan memasukkan aspirasi dan kepentingan masyarakat yang diwakilinya ke dalam pasal-pasal undang-undang yang dibuat.

Berdasarkan deskripsi ini akan diperoleh gambaran seperti apa DPR telah menjalankan fungsi legislasinya yang biasa dijadikan sebagai indikator adanya proses demokratisasi. Sebaliknya kurang atau tidak berjalannya fungsi legislasi yang dimiliki oleh DPR dapat dijadikan kurang atau tidak berjalannya proses demokratisasi, sebab DPR sendiri merupakan lembaga/perangkat demokrasi.

Pada hakikatnya fungsi utama dari legislatif adalah membuat undangundang (legislasi), hal ini juga sejalan dengan fungsi-fungsi yang lain seperti fungsi pengawasan (controlling) juga merupakan bagian fungsi legislasi, karena dalam menjalankan fungsi pengawasan tentunya terlebih dahulu melahirkan peraturan perundang-undangan yang dijadikan sebagai acuan dalam melakukan pengawasan terhadap pemerintah dalam menjalankan fungsinya.

Begitu juga dengan fungsi anggaran (budgeting) yang merupakan sebagian dari fungsi legislasi karena untuk menetapkan Anggaran Pendapatan dan Belanja Negara (APBN) juga ditetapkan dengan undang-undang APBN setiap tahun anggaran. Fungsi pokok dari DPR dalam hal ini adalah pembentukan undangundang sebagai landasan hukum bagi pemerintah dalam membuat kebijakan publik. Sebagaimana dijelaskan bahwa dalam konsep demokrasi menempatkan partisipasi sebagai intinya, yang berarti menghendaki diikutsertakannya masyarakat dalam pembuatan kebijakan publik (public policy). Apabila diikuti secara seksama pasal-pasal yang mengatur DPR di dalam UUD 1945, dapat 
dikatakan DPR mempunyai tugas yang sangat penting dalam kehidupan ketatanegaraan Indonesia (Gunawan 2008: 70).

DPR adalah bentuk nyata dari hasil konsepsi perwakilan di Indonesia, sehingga dianggap mampu merumuskan kemauan dan keinginan dari rakyat yang dapat dimulai dari perencanaan, pembuatan, persetujuan suatu rancangan undangundang sampai disetujui menjadi undang-undang, sebab setiap undang-undang yang disahkan akan memberikan konsekuensi dan keterikatan rakyat Indonesia terhadap undang-undang tersebut. Lembaga perwakilan bukan berarti dapat semaunya memutuskan segala kebijakan umum mengatasnamakan rakyat tanpa adanya kontrol dari rakyat yang diwakilinya, sebab suatu sistem pemerintahan yang tidak memiliki kontrol akhir atas agenda pemerintahan umum dapat dianggap sebagai sistem tidak demokratis.

Pengawasan (kontrol) pada dasarnya diarahkan untuk menghindari adanya kemungkinan penyelewengan atau penyimpangan atas tujuan yang akan dicapai. Melalui pengawasan diharapkan dapat membantu melaksanakan kebijakan yang telah ditetapkan untuk mencapai tujuan yang telah direncanakan secara efektif dan efisien. Melalui pengawasan tercipta suatu aktivitas yang berkaitan erat dengan penentuan atau evaluasi mengenai sejauhmana pelaksanaan kerja sudah dilaksanakan. Pengawasan juga dapat mendeteksi sejauhmana kebijakan pimpinan dijalankan dan sampai sejauhmana penyimpangan yang terjadi dalam pelaksanaan kerja tersebut. Hasil pengawasan ini harus dapat menunjukkan sampai di mana terdapat kecocokan dan ketidakcocokan dan menemukan penyebab ketidakcocokan yang muncul.

Dalam konteks membangun manajemen pemerintahan publik yang bercirikan good governance (tata kelola pemerintahan yang baik), pengawasan merupakan aspek penting untuk menjaga fungsi pemerintahan berjalan sebagaimana mestinya, sehingga pengawasan menjadi sama pentingnya dengan penerapan good governance itu sendiri. Terkait dengan akuntabilitas publik, pengawasan merupakan salah satu cara untuk membangun dan menjaga legitimasi warga masyarakat terhadap kinerja pemerintahan dengan menciptakan suatu sistem pengawasan yang efektif, baik pengawasan intern (internal control) 
maupun pengawasan ekstern (external control), selain mendorong adanya pengawasan masyarakat (social control).

Konsep pengawasan seperti uraian di atas menunjukkan pengawasan merupakan bagian dari fungsi manajemen, karena pengawasan dianggap sebagai bentuk pemeriksaan atau pengontrolan dari pihak yang lebih atas kepada pihak di bawahnya. Dalam ilmu manajemen, pengawasan ditempatkan sebagai tahapan terakhir dari fungsi manajemen. Dari segi manajerial, pengawasan mengandung makna pula sebagai pengamatan atas pelaksanaan seluruh kegiatan unit organisasi yang diperiksa untuk menjamin agar seluruh pekerjaan yang sedang dilaksanakan sesuai dengan rencana dan peraturan atau suatu usaha agar suatu pekerjaan dapat dilaksanakan sesuai dengan rencana yang telah ditentukan, dan dengan adanya pengawasan dapat memperkecil timbulnya hambatan, sedangkan hambatan yang telah terjadi dapat segera diketahui yang kemudian dapat dilakukan tindakan perbaikannya, sedangkan dari segi hukum administrasi negara, pengawasan dimaknai sebagai proses kegiatan yang membandingkan apa yang dijalankan, dilaksanakan, atau diselenggarakan dengan apa yang dikehendaki, direncanakan, atau diperintahkan.

\section{Wewenang DPR}

Salah satu wewenang DPR adalah membentuk undang-undang yang dibahas dengan Presiden untuk mendapat persetujuan bersama. Membahas dan memberikan persetujuan atau tidak memberikan persetujuan terhadap Peraturan Pemerintah Pengganti Undang-Undang yang diajukan oleh Presiden untuk menjadi undang-undang (Gunawan 2008: 70).

Wewenang lain DPR adalah menerima rancangan undang-undang yang diajukan oleh DPD berkaitan dengan otonomi daerah, hubungan pusat dan daerah, pembentukan dan pemekaran serta penggabungan daerah, pengelolaan sumber daya alam dan sumber daya ekonomi lainnya, serta yang berkaitan dengan perimbangan keuangan pusat dan daerah serta membahas rancangan undangundang tersebut bersama Presiden dan DPD sebelum diambil persetujuan bersama antara DPR dan Presiden. 
DPR juga berwenang untuk membahas rancangan undang-undang yang diajukan oleh Presiden atau DPR yang berkaitan dengan otonomi daerah, hubungan pusat dan daerah, pembentukan dan pemekaran serta penggabungan daerah, pengelolaan sumber daya alam dan sumber daya ekonomi lainnya, serta perimbangan keuangan pusat dan daerah, dengan mengikutsertakan DPD sebelum diambil persetujuan bersama antara DPR dan Presiden.

DPR juga memberikan persetujuan kepada Presiden untuk menyatakan perang, membuat perdamaian dan perjanjian dengan negara lain, serta membuat perjanjian internasional lainnya yang menimbulkan akibat yang luas dan mendasar bagi kehidupan rakyat yang terkait dengan beban keuangan negara dan/atau mengharuskan perubahan atau pembentukan undang-undang. DPR juga berwenang untuk memberikan pertimbangan kepada Presiden dalam hal pemberian amnesti, dan abolisi. DPR juga berwenang memberikan pertimbangan kepada Presiden dalam hal mengangkat duta besar dan menerima penempatan duta besar negara lain, memilih anggota BPK dengan memerhatikan pertimbangan DPD. DPR juga berwenang membahas dan menindaklanjuti hasil pemeriksaan atas pertanggungjawaban keuangan negara yang disampaikan oleh BPK.

Memperhatikan Pasal 23 UUD 1945, bahwa APBN ditetapkan tiap-tiap tahun dengan undang-undang, dan apabila DPR tidak menyetujui anggaran yang diusulkan presiden, maka pemerintah menjalankan anggaran yang tahun lalu, maka dapat diasumsikan bahwa dalam hal penetapan pendapatan dan belanja negara kedudukan DPR lebih kuat daripada pemerintah yang menunjukan secara filosofis yuridis sebagai tanda dari kedaulatan rakyat. Dengan demikian dalam konsepsi keuangan negara, maka hakikat APBN adalah kedaulatan rakyat yang diamanatkan kepada DPR.

Menurut Saidi (2008: 47), dikatakan bahwa pertanggungjawaban keuangan negara dapat dilihat dari 2 (dua) sisi, yaitu:

a. pertanggungjawaban keuangan negara horizontal, yaitu: pertanggungjawaban pelaksanaan APBN yang diberikan pemerintah kepada DPR. Hal ini terjadi karena sistem ketatanegaraan yang berdasarkan UUD 1945 telah menentukan 
kedudukan pemerintah dan DPR sederajat. Hal ini dilakukan dalam bentuk persetujuan terhadap RUU Perhitungan Anggaran Negara.

b. Pertanggungjawaban keuangan vertikal, yaitu pertanggungjawaban keuangan yang dilakukan oleh setiap otoristor dari setiap departemen atau lembaga negara non departemen yang menguasai bagian anggaran, termasuk di dalamnya pertanggungjawaban bendaharawan kepada atasannya dan pertanggungjawaban para pimpinan proyek. Pertanggungjawaban keuangan ini pada akhirnya disampaikan kepada presiden yang diwakili oleh menteri keuangan selaku pejabat tertinggi pemegang tunggal keuangan negara.

Sesuai dengan konsep di atas, maka dapat dikatakan bahwa pertanggungjawaban keuangan negara merupakan konsekuansi logis dari kesediaan pemerintah melaksanakan APBN yang telah disetujui oleh DPR. Dalam hal pengelolaan keuangan negara atau APBN, pertanggungjawaban keuangan negara dituangkan ke dalam perhitungan anggaran negara sebagai kuasa dari DPR kepada pemerintah memberikan dasar kuat bahwa yang berhak menerima pertanggungjawaban keuangan negara adalah DPR.

Pelaksanaaan fungsi pengawasan, lembaga DPR dilengkapi dengan hak untuk meminta keterangan (interpelasi), hak untuk menyelidiki (angket), hak menyatakan pendapat (resolusi), hak untuk memperingatkan secara tertulis (memorandum), dan bahkan hak untuk menuntut pertanggungjawaban (impeachment) kepada pemerintah. Dalam pelaksanaan fungsi legislasi, DPR mempunyai hak/kewajiban untuk mengajukan rancangan undangundang, hak amandemen atau hak untuk mengubah atau bahkan menolak sama sekali rancangan undang-undang yang diajukan oleh pemerintah. DPR berhak mengajukan RAPBN dan berhak mengubah dengan mengurangi ataupun menambah anggaran yang diajukan pemerintah. Untuk dapat menjalankan tugas dan wewenangnya tersebut secara efektif, maka DPR perlu diberikan sejumlah hak yaitu hak interpelasi, hak angket dan hak menyatakan pendapat. Ketiga hak ini merupakan kewenangan atau hak DPR sebagai suatu lembaga.

Hak interpelasi adalah hak untuk meminta keterangan kepada pemerintah tentang sesuatu kebijakan pemerintah yang penting dan strategis serta berdampak 
luas; hak angket adalah hak DPR untuk melakukan suatu penyelidikan terhadap kebijakan pemerintah yang penting dan strategis yang diduga bertentangan dengan peraturan perundangan; sedangkan hak menyatakan pendapat adalah hak DPR sebagai lembaga untuk menyatakan pendapat terhadap kebijakan pemerintah atau mengenai kejadian luar biasa yang terjadi di tanah air atau situasi dunia internasional disertai dengan rekomendasi penyelesaiannya.

\section{Pembahasan rancangan undang-undang APBN}

Anggaran Pendapatan dan Belanja Negara (APBN) adalah rancangan anggaran tahunan untuk penerimaan dan pemasukan yang dimiliki oleh negara untuk segala kebutuhan Negara. APBN berisi daftar sistematis dan terperinci yang memuat rencana penerimaan dan pengeluaran negara selama satu tahun anggaran (1 Januari - 31 Desember). APBN, Perubahan APBN, dan Pertanggungjawaban APBN setiap tahun ditetapkan dengan undang-undang.

Setiap tahunnya pemerintah menyusun APBN yang landasan hukumnya serta tata cara penyusunan APBN terdapat di dalam UUD 1945 Pasal 23 ayat (1), (2) dan (3). Pada Pasal 23 ayat (1) UUD 1945 disebutkan bahwa Anggaran Pendapatan dan Belanja Negara (APBN) sebagai wujud dari pengelolaan keuangan negara ditetapkan setuiap tahun dengan undang-undang dan dilaksanakan secara terbuka dan bertanggungjawab untuk sebesar-besarnya kemakmuran rakyat. Pada Pasal 23 ayat (2) disebutkan bahwa Rancangan Undang-Undang Anggaran Pendapatan dan Belanja Negara diajukan oleh Presiden untuk dibahas bersama DPR dengan memerhatikan pertimbangan Dewan Perwakilan Daerah. Pada Pasal 23 ayat (3) disebutkan apabila DPR tidak menyetujui RAPBN yang diusulkan Presiden, pemerintah menjalankan APBN tahun lalu.

Setelah APBN ditetapkan dengan undang-undang, pelaksanaan APBN dituangkan lebih lanjut dengan Peraturan Presiden. Berdasarkan perkembangan, di tengah-tengah berjalannya tahun anggaran, APBN dapat mengalami revisi/ perubahan. Untuk melakukan revisi APBN, Pemerintah harus mengajukan RUU Perubahan APBN untuk mendapatkan persetujuan DPR. Dalam keadaan darurat (misalnya terjadi bencana alam), Pemerintah dapat melakukan pengeluaran yang belum tersedia anggarannya. Selambatnya 6 (enam) bulan setelah tahun anggaran 
berakhir, Presiden menyampaikan RUU tentang Pertanggungjawaban Pelaksanaan APBN kepada DPR berupa Laporan Keuangan yang telah diperiksa oleh Badan Pemeriksa Keuangan.

Berdasarkan Pasal 15 ayat (1) Undang-undang Nomor 17 Tahun 2003 tentang Keuangan Negara (UU No. 17 Tahun 2003), pemerintah pusat diharuskan mengajukan RUU tentang APBN disertai nota keuangan dan dokumen-dokumen pendukung kepada DPR pada bulan Agustus tahun sebelumnya. Dalam tahapan ini masing-masing pihak melakukan kegiatan yang dilakukan secara simultan antara lain sebagai berikut:

a. Pemerintah (diwakili oleh menteri keuangan)

Peran pemerintah dalam tahapan ini dimulai dengan pengajuan RUU tentang APBN beserta nota keuangan pada tanggal 16 Agustus. Pengajuan tersebut disampaikan oleh Presiden melalui pidato pengantar RUU APBN beserta nota keuangan dalam rapat paripurna DPR. Dalam hal ini bila presiden berhalangan hadir, maka pidato tersebut digantikan oleh wakil presiden dan jika pada tanggal 16 Agustus jatuh pada hari libur maka penyampaian pidato presiden dilakukan pada hari kerja sebelumnya. Dalam rapat paripurna selanjutnya, fraksi-fraksi di DPR diberikan kesempatan untuk diberikan kesempatan menyampaikan pendapat melalui pandangan fraksi atas RUU tentang APBN dan pemerintah diberikan kesempatan untuk menjawab.

b. Dewan Perwakilan Rakyat (DPR)

Badan anggaran setelah pemerintah menyerahkan RAPBN dan nota keuangan pada DPR, maka badan anggaran untuk melakukan pembahasan bersama pemerintah seperti tahapan pembicaraan pendahuluan, maka pada tahapan ini komisi VII dan komisi XI jika melakukan pembahasan mengenai asumsi makro. Badan anggaran selanjutnya membentuk panja-panja yang melakukan pembahasan lebih terinci. Keanggotaan panja yang berasal dari anggaran dari badan anggaran pihak pemerintah yang ditunjuk dalam rapat kerja.

Hasil panja tersebut kemudian dibahas dan disahkan dalam rapat kerja badan anggaran dan pemerintah setelah komisi melakukan pembahasan mengenai 
penyempurnaan RAPBN yang termasuk ruang lingkup tugasnya, selanjutnya dilakukan sinkronisasi yang dilakukan secara simultan, yaitu:

1) Komisi menyampaikan hasil pembahasan yang mengajukan usul penyempurnaan RAPBN yang termasuk ruang lingkup tugasnya;

2) Badan anggaran melakukan sinkronisasi, kemudian hasilnya disampaikan kepada konisi untuk lebih disempurnakan;

3) Hasil penyempurnaan komisi disertai kembali kepada badan anggaran untuk dilakukan sinkronisasi kembali;

4) Hasil sinkronisasi ini kemudian disampaikan oleh badan anggaran dalam rapat paripurna pengambilan keputusan atas RUU APBN dan nota keuangannya.

c. Komisi-komisi

1) Setelah penyerahan nota keuangan, komisi melakukan pembahasan dengan lembaga/kementerian teknis pasangan kerjanya mengenai penyelesaian terakhir RUU tentan APBN terutama mengenai alokasi anggaran untuk program, proyek atau kegiatan kementerian/lembaga tahun anggaran berikutnya;

2) Proses pembahasan dilakukan komisi antara lain:

a) Komisi melakukan pembahasan dan mengajukan usul penyempurnaan RAPBN yang termasuk ruang lingkup tugasnya;

b) Hasil pembahasan tersebut disampaikan kepada badan anggaran untuk disinkronisasi;

c) Hasil sinkronisasi badan anggaran selanjutnya disempurnakan kembali berdasarkan penyampaian usul komisi;

d) Hasil penyempurnaan oleh komisi disampaikan kembali badan anggaran, kemudian disampaikan panitia anggaran dalam rapat paripurna pengambilan keputusan atas RUU APBN dan Nota Keuangan.

\section{Kedudukan DPR dalam penetapan dan pengawasan APBN}

Pasal 23 ayat (1) UUD 1945, bahwa Anggaran Pendapatan Belanja Negara (APBN) sebagai wujud dari keuangan pengelolaan keuangan Negara. DPR dengan Presiden merupakan dua lembaga negara yang berlainan akan tetapi dalam 
tugas legislatif kedua lembaga tersebut mempunyai tugas yang sama terutama dalam membuat undang-undang serta APBN. Demikian juga halnya menentukan undang-undang APBN harus ada persetujuan dari DPR, dan jika DPR menolak untuk memberikan persetujuan terhadap anggaran yang diusulkan pemerintah, maka pemerintah menjalankan anggaran tahun yang lalu (Kusnardi dan Ibrahim 2009: 214).

Negara tidak dapat bertahan tanpa uang dan pembiayaan, oleh sebab itu, setiap negara yang berdaulat dan demokratis, memiliki anggota (budget) untuk kebutuhan negaranya untuk 1 (satu) tahun anggaran. Anggaran tersebut diadakan untuk memenuhi kebutuhan Negara dalam menjalankan kehidupan bernegara dan bermasyarakat (Ashshidiqie 2011: 160). Anggaran negara secara sempit diartikan sebagai APBN yang artinya adalah rencana kerja yang diperhitungkan dengan keuangan yang disusun secara sistematis, yang mencakup rencana penerimaan dan rencana pengeluaran untuk satu anggaran yang disusun oleh pemerintah pusat dan telah disetujui oleh DPR.

Pada umumnya anggaran selalu dipersiapkan oleh pemerintah (eksekutif). Hal ini didasarkan karena pihak eksekutif yang memiliki instrumen yang berhubungan dengan anggaran. Lembaga yang mempersiapkan rencana anggaran pada umumnya disebut dengan Kantor Anggaran Budget (Budget Officer). Melalui lembaga inilah yang bertanggungjawab dalam merencanakan, menyusun anggaran dan mencari sumber anggaran yang diperlukan. Jadi ada dua fungsi kantor anggaran, yaitu:

a. Fungsi menyusun RAPBN secara sistematis; dan

b. Fungsi untuk mencari sumber anggaran yang diperlukan.

Pembentukan undang-undang tentang APBN berbeda dengan pembentukan undang-undang lainnya karena Pasal 23 ayat (2) UUD 1945 yang menegaskan RUU APBN diajukan oleh pemerintah untuk dibahas bersama DPR dengan pertimbangan DPD berdasarkan ketentuan Pasal 23 ayat (2) UUD 1945, Presiden memperoleh kewenangan berdasarkan atribusi untuk mengajukan RUU tentang APBN. DPR sendiri tidak berwenang mengajukan RUU tentang APBN kecuali 
RUU lainnya. Hal ini dilatarbelakangi oleh bahwa Presiden bersama-sama jajarannya lebih banyak mengetahui kebutuhan Negara dibandingkan DPR.

Keterlibatan DPR sekedar membahas tentang RUU APBN yang diajukan oleh Presiden. Dalam proses pembahasannya, DPR tidak wajib menyetujui RUU tentang APBN bila dianggap belum memenuhi tuntutan perkembangan ke depan, DPR berwenang menolaknya. Presiden sebelum mengajukan RUU tentang APBN diharapmkan telah mengantisipasi perkembangan kedapan untuk kepentingan Negara sehingga tidak memperoleh penolakan dari DPR. RUU tentang APBN, apabila telah menjadi undang-undang tentang APBN berarti wajib diundangkan dalam lembaran negara agar dianggap secara hukum diketahui keberlakuannya. Undang-undang tentang APBN memiliki jangka waktu satu tahun, sedangkan undang-undang lain masa berlakunya tidak ditentukan.

Setelah cukup satu tahun keberlakuan UU APBN, berarti Presiden berwenang lagi mengajukan tentang RUU APBN kepada DPR untuk mendapatkan persetujuan UU tentang APBN. DPR tidak wajib memberikan persetujuan RUU tentang APBN yang diajukan oleh Presiden, dan jika terjadi penolakan, berarti Presiden memberlakukan undang-undang tentang APBN tahun lalu agar tidak terjadi kekosongan atau kevakuman hukum terhadap pembiayaan pemerintah negara untuk ke depannya.

Di Indonesia sesuai dengan UU No. 17 Tahun 2003, kekuasaan pengelolaan keuangan negara ada di tangan Presiden, yang dikuasakan kepada Menteri Keuangan. Dengan demikian, Kementerian Keuangan dapat disebut sebagai kantor anggaran yang bertugas menyusun RAPBN. Setelah pihak pemerintah menyusun anggaran, maka diperlukan pembahasan dan persetujuan melalui lembaga parlemen.

Akibat semakin berkembangnya pengaruh badan legislatif di bidang legislatif, maka peranannya di bidang pengawasan bertambah menonjol. Badan legislatif berkewajiban untuk mengawasi aktivitas badan eksekutif, agar sesuai dengan kebijakan yang telah ditetapkannya. Pengawasan dilakukan melalui sidang panitia-panitia legislatif dan melalui hak-hak kontrol yang khusus, seperti hak bertanya, interpelasi dan sebagainya (Budiardjo 2008: 326). 
Adanya rumusan yang tegas dan konkrit dalam teks UUD 1945 yang menjelaskan bahwa kedudukan DPR adalah kuat, mungkin masih perlu dielaborasi dan dikembangluaskan hingga mendapat arti, pengakuan dan pelaksanaan dari semua pihak yang mengelola negara. Demikian juga terhadap pihak anggota DPPR sendiri rumusan dan pemahaman penjelasan ini perlu disimak lebih mendalam dan menjadi pangkal tolok ukur atau kompas dalam tugas dan wewenang sebagai anggota DPR (Marbun 1992:11).

Pemerintah sendiri dibentuk dalam rangka penyelenggaraan kegiatan bernegara untuk mencapai tujuan bernegara. Dalam konteks Indonesia, maka APBN menjadi instrumen untuk mencapai tujuan negara tersebut yaitu kemakmuran rakyat.

Keuangan negara yang penggunanya menurut Pasal 23 ayat (1) UUD 1945 digunakan untuk kemakmuran rakyat secara prinsipil menurut Dian Puji N. Simatupang merupakan norma-norma etis yang melandasi penggunaan pengelolaan dan pertanggungjawaban keuangan Negara. Oleh sebab itu, kebijakan keuangan Negara harus memiliki legitimasi daripada hanya untuk kepentingan kelompok tertentu (Simatupang 2011: 138).

Partisipasi masyarakat tersebut merupakan konsekuensi dianutnya paham demokrasi yang memiliki peranan yang sangat penting bersamaan dengan diakuinya hak-hak sipil warga masyarakat. Menurut Amartya Sen (1999: 16), keberlangsungan demokrasi dan jaminan hak-hak sipil politik rakyat dapat mencegah terjadinya kelaparan dan bencana ekonomi.

Dengan demikian, demokrasi dan kesejahteraan rakyat memiliki tautan yang erat. Menurut Joe Fernandez sebagaimana yang dikutip oleh Mei Susanto (2013: 204), masyarakat yang terampas (edeprived) hak-hak sipilnya dan tanpa kebebasan politik mungkin tidak mengalami kekurangan dalam konteks ekonomi, politik mungkin tidak mengalami kecurangan dalam konteks ekonomi, tetapi mereka kehilangan hak untuk ambil bagian dalam keputusan atas hal-hal yang menentukan kehidupannya di ranah publik. Hal ini juga menunjukkan pentingnya demokrasi perwakilan yang partisipatif dalam mendorong APBN yang sebesarbesarnya untuk kesejahteraan rakyat. 
Dalam hal APBN sebagai instrumen mengatasi kesenjangan sosial masyarakat dan permasalahan keadilan sosial, Dian Puji N. Simatupang (2011: 138), menyebutkan bahwa:

"APBN harus dapat secara optimal mengatasi masalah kebutuhan sosial masyarakat (social need gep) dalam bentuk pendidikan, kesehatan, dan pangan. Di sisi lain kebijakan APBN harus mempunyai komitmen mendasar pada keadilan sosial (social equity) yang berusaha untuk mewujudkan pos belanja dalam anggaran secara sistematis untuk mewujudkan kesejahteraan dan pemerataan. Konsep keadilan sosial dalam kebijakan APBN dirancang oleh pemerintah sebagai penyusun anggaran Negara untuk meningkatkan potensi perubahan dalam birokrasi agar mewujudkan komitmen terhadap kesejahteraan rakyat. Selain itu, memungkinkan masyarakat untuk berpartisipasi dalam anggaran negara dengan memberikan kesempatan yang seluas-luasnya dan merealisasikan belanja pembangunan yang telah disediakan”.

Apabila kebijakan APBN berorientasi pada pengentasan permasalahan kesenjangan sosial masyarakat, maka hal tersebut menunjukkan penyelenggara negara berkomitmen pada upaya pemenuhan tujuan bernegara pada upaya pemenuhan tujuan bernegara (bestuurzorg). Apabila APBN hanya berorientasi pada pengamanan kesenjangan sosial, maka dapat diprediksi pemenuhan tujuan bernegara tidak akan tercapai.

Dalam konteks APBN sebagai pertemuan kebijakan ekonomi dan kebijakan sosial, maka APBN memiliki peranan yang strategis tidak hanya berbicara secara teknis kebijakan fiskal dan keuangan, melainkan juga masalah kepentingan masyarakat sehingga APBN juga menjadi tempat pergulatan atau tawar menawar politik. Persoalan utama kaum miskin di negara berkembang adalah tidak memiliki posisi tawar atau dapat memengaruhi kebijakan publik pemerintah. Jarang terjadi bahwa kelompok miskin mampu memperbaiki posisi tawarnya kecuali dengan gerakan sosial atau pemberontakan yang digalang melalui semangat solidaritas (Susanto 2013: 145).

Permasalahan kesejahteraan rakyat khususnya kemiskinan berpeluang untuk lebih diselesaikan dalam sistem demokrasi yang partisipatif, dimana rakyat miskin mampu menyuarakan kepentingannya, sehingga proses politik APBN dapat berpihak pada pengentasan kemiskinan tersebut. Di sinilah pentingnya hak 
budget parlemen yang berpihak kepada kesejahteraan rakyat tersebut. Ini artinya APBN sebagai instrumen mencapai tujuan bernegara yaitu kesejahteraan rakyat, ditopang dengan sistem demokrasi perwakilan partisipatif melalui parlemen untuk mendorong APBN sebesar-besarnya untuk kemakmuran rakyat.

Permasalahan yang muncul adalah penguatan sentra hukum dan peraturan dan peraturan perundang-undangan yang memungkinkan kebijakan anggaran Negara sesuai dengan filosofi kedaulatan-kedaulatan tidak mampu diharapkan dari kesalahan redaksional perubahan Pasal 23 ayat (1) UUD 1945. Kesalahan redaksional itu karena salah satu semangat perubahan UUD 1945 adalah penguatan derajat kedaulatan rakyat melalui parlemen, namun perumusan Pasal 23 ayat (1) UUD 1945 tidak memenuhi prinsip kedaulatan rakyat tersebut.

Pasal 23 ayat (1) UUD 1945, APBN sebagai wujud kebijakan anggaran Negara ditentukan salah kaprah sebagai wujud pengelolaan keuangan Negara, rumusan demikian secara lugas memosisikan Negara sebagai penguasa dalam kebijakan anggaran. APBN harus mewujudkan kesejahteraan rakyat, dimana rakyat yang menjadi subjek dalam penganggaran Negara (Simatupang 2011: 140).

Kelengkapan DPR yang bersifat tetap menurut perimbangan dan pemerataan jumlah anggota tiap-tiap fraksi. Susunan dan keanggotaan panitia anggaran terdiri atas anggota-anggota seluruh komisi yang dipilih oleh komisi dengan memerhatikan perimbangan jumlah anggota dan usulan dari fraksi. Pimpinan panitia anggaran merupakan satu kesatuan yang bersifat kolektif, terdiri satu orang ketua dan empat orang wakil ketua yang dipilih dari anggota panitia anggaran berdasarkan prinsip musyawarah untuk mufakat dan proporsional menurut perimbangan jumlah anggota tiap-tiap fraksi di DPR. Pimpinan panitia anggaran tidak dapat rangkap dengan keanggotaan pimpinan alat kelengkapan DPR lainnya, sedangkan tugas panitia anggaran adalah:

a. Melaksanakan pembahasan APBN;

b. Melaksanakan tugas bisa melakukan hal-hal sebagai berikut:

1) Mengadakan rapat kerja dengan presiden, yang dapat diwakili oleh menteri; 
2) Mengadakan dengar pendapat atau rapat dengar pendapat umum baik atas permintaan panitia anggaran maupun atas permintaan lain;

3) Mengadakan konsultasi dengan DPD;

4) Mengadakan studi banding atas persetujuan pimpinan DPR yang hasilnya dilaporkan dalam rapat panitia anggaran untuk ditentukan tindak lanjutnya;

5) Mengusulkan badan musyawarah hal yang dipandang perlu untuk dimasukkan dalam acara DPR;

6) Membuat inventarisasi, masalah pada akhir masa keanggotaan DPR, baik yang sudah maupun yang belum terselesaikan untuk dapat dipergunakan sebagai bahan oleh panitia anggaran pada masa keanggotaan berikutnya.

APBN merupakan instrumen penting bagi bekerjanya suatu pemerintahan.

Tidak ada pemerintahan yang dapat berjalan tanpa adanya pendapatan dan pengeluaran negara (Ashshidiqie 2011: 832). Pengawasan yang digambarkan dalam siklus anggaran atau budget cyclus terlihat seakan-akan terpisah padahal sebenarnya pengawasan yang sebenarnya merupakan bagian yang tidak terpisahkan dari setiap siklus anggaran. Dengan demikian, pengawasan merupakan instrumen pengendalian yang melekat.

Badan pengawasan keuangan dan pembangunan melakukan pengawasan terhadap pelaksanaan APBN sesuai dengan peraturan perundang-undangan yang berlaku. Inspektur Jenderal Departemen/Pimpinan Unit Pengawasan pada lembaga di tingkat pusat, Kepala Badan Pengawasan Keuangan dan Pembangunan dan Gubernur pada tingkat daerah menampung pengaduan dari masyarakat dunia usaha mengenai masalah-masalah yang timbul sebagai akibat dari pelaksanaan APBN dan mengambil langkah-langkah penyesuaian sesuai dengan kewenangannya (Sidhi 92-93).

Pada setiap tahap dalam siklus anggaran pengawasan merupakan sarana untuk menghubungkan target dengan realisasi setiap program/kegiatan/proyek yang harus dilaksanakan oleh pemerintah. Fungsi pengawasan dapat dilakukan setiap saat, baik selama proses manajemen/administrasi berlangsung maupun setelah berakhir untuk mengetahui pencapaian tujuan suatu organisasi/unit kerja 
dengan kata lain fungsi pengawasan harus dilakukan terhadap perencanaan dan pelaksanaannya. Kegiatan pengawasan fungsi manajemen bermaksud untuk mengetahui tingkat keberhasilan dan kegagalan yang terjadi (Tjandra 2013: 154).

Menurut Bagir Manan (2006: 8), bahwa bagaimanapun juga tetap diperlukan suatu mekanisme saling mengawasi antara cabang-cabang kekuasaan yang satu dengan cabang kekuasaan yang lain. Pemikiran mengenai mekanisme saling mengawasi dan kerja sama ini telah melahirkan teori-teori modifikasi atas ajaran pemisahan kekuasaan yaitu teori pembagian kekuasaan (distribution of power) yang menekankan pada pembagian fungsi-fungsi pemerintahan, bukan pada pemisahan organ, dan teori cheks and balances.

Jimly Asshidieqie (2010: 153) menyebutkan di Indonesia, fungsi lembaga perwakilan atau parlemen biasanya dibedakan ke dalam tiga fungsi, yaitu:

a. Fungsi legislasi (legislative);

b. Fungsi pengawasan (control) dan;

c. Fungsi anggaran (budget).

Mekanisme penetapan dan pengawasan DPR terhadap APBN di Indonesia yaitu UUD 1945 Pasal 23 ayat (1) mengatur hak DPR untuk bersama-sama pemerintah menetapkan APBN, dengan adanya Badan Pemeriksa Keuanagan yang ditugaskan memeriksa tanggung jawab tentang keuangan negara, dimana hasil pemeriksaan itu harus diberitahukan kepada DPR, maka pengawasan APBN ini sebenarnya dapat dilakukan secara efektif.

\section{Simpulan dan Saran}

\section{Simpulan}

Pasal 23 UUD 1945 merupakan sumber wewenang DPR secara formil dalam penetapan APBN, yang sekaligus memberikan pemahaman filosofis yuridis sebagai bentuk penjelmaan kedaulatan rakyat. Kedudukan DPR dalam penetapan dan pengawasan APBN merupakan wujud dari pengelolaan keuangan negara, sebagai tugas yang sama dengan pemerintah, terutama dalam membuat undangundang dan menetapkan APBN. DPR dapat saja menolak rancangan undangundang yang terkait dengan APBN dan jika DPR menolak untuk memberikan 
persetujuan terhadap anggaran yang diusulkan pemerintah, maka pemerintah menjalankan anggaran tahun yang lalu.

\section{Saran}

Akibat hukum penetapan APBN oleh DPR adalah disahkannya APBN, maka pemerintah dapat melaksanakan kedaulatan rakyat berdasarkan kerakyatan yang dipimpin oleh hikmat kebijaksanaan dalam permusyawaratan/perwakilan, perlu diwujudkan lembaga permusyawaratan rakyat, lembaga perwakilan rakyat, dan lembaga perwakilan daerah yang mampu mengejawantahkan nilai-nilai demokrasi, serta dapat menyerap dan memperjuangkan aspirasi rakyat. 


\section{DAFTAR PUSTAKA}

\section{Buku:}

Bagir Manan. 2006. Lembaga Kepresidenan. Yogyakarta: FH UII Press.

Dian Puji Simatupang. 2011. Paradoks Rasionalitas Perluasan Ruang Lingkup Keuangan Negara dan Implikasinya Terhadap Kinerja Keuangan Pemerintah. Jakarta: Badan Penerbit FH UI.

Djafar Muhammad Saidi. 2008. Hukum Keuangan Negara, Jakarta: RajaGrafindo Persada.

Ismail Suny. 2004. Kedudukan MPR, DPR dan DPD Pasca Amandemen 1945, Surabaya: Fakultas Hukum Unair.

Jimly Asshidieqie. 2011. Pokok-Pokok Hukum Tata Negara Republik Indonesia Pasca Reformasi. Jakarta: Bhuana Ilmu Populer.

---------. 2011. Hukum Tata Negara dan Pilar-Pilar Demokrasi. Jakarta: Sinar Grafika.

Marbun. B.N. 1992. DPR-RI Pertumbuhan dan Cara Kerjanya. Jakarta: Gramedia Pustaka.

Markus Gunawan. 2008. Buku Pintar Calon Anggota dan Anggota Legislatif. Jakarta: Visimedia.

Mei Susanto. 2013. Hak Budget Parlemen di Indonesia. Jakarta: Sinar Grafika.

Miriam Budiardjo. 2008. Dasar-Dasar Ilmu Politik. Jakarta: Gramedia Pustaka Utama.

Moh. Kusnardi dan Hermaily Ibrahim. 2009. Pengantar Hukum Tata Negara. Jakarta: Sinar Bakti.

Muhammad Jafar. 2013. Hukum Keuangan Negara. Jakarta: PT. RajaGrafindo Persada.

Purnama Sidhi. Tanpa Tahun. Sistem Administrasi Negara Republik Indonesia, Jakarta: Haji Masagung.

Riawan Tjandra, W. 2013. Hukum Keuangan Negara. Jakarta: Grasindo.

Sen Amartya. 1999. Development as Freedom. New Delhi: Oxford University Press.

Yuliandri. 2011. Asas-Asas Pembentukan Peraturan Perundang-undangan yang Baik. Jakarta: RajaGrafindo Persada. 


\section{BIODATA PENULIS}

$\begin{array}{ll}\text { Nama } & \text { : Julpikar, S.H., M.H } \\ \text { Pekerjaan } & \text { : Dosen Fakultas Hukum Universitas Muhammadiyah Sumatera } \\ & \text { Utara } \\ \text { Jabatan } & \text { : Asisten Ahli } \\ \text { Nomor HP } & : \text { 081260606695 } \\ \text { E-mail } & \text { : julfikarsyarno@ gmail.com } \\ \text { Alamat Kantor } & \text { : Jl. Muchtar Basri No. } 3 \text { Medan }\end{array}$ 